\title{
Family Agritourist Enterprises in Poland: Preliminary Survey Results
}

\author{
Sławomir Dorocki, Anna Irena Szymańska, Małgorzata Zdon-Korzeniowska
}

\begin{abstract}
Objective: The main goal of the paper is the evaluation of agritouristic enterprises, as a specific type of family owned businesses, in terms of their market and entrepreneurial behaviour and the behaviour connected with generating innovation. The attempt has been made to define the advantages and disadvantages of family-run business in the opinion of the agritouristic enterprises.

Research Design \& Methods: Achievement of the above-mentioned goal was based on the analysis of professional literature, and direct research supported by direct questionnaire surveys and individual in-depth interviews. The empirical research was conducted in the period from January to March 2012.
\end{abstract}

Findings: Agritourist enterprises are self-defined as family enterprises. They can see and appreciate benefits from running a family business as well as their advantage in being innovative and strive to introduce changes in their businesses.

Implications \& Recommendations: In the opinion of the authors of this paper, agritourist farms are a very special example of family entrepreneurship.

Contribution \& Value Added: Issues analysed in this study are relatively new and poorly covered by the literature in the field. It is a certain novelty to analyse family entrepreneurship in agritourism in addition to being an interesting area of scientific exploration.

Article type: research paper

Keywords: family enterprises; agritourist family enterprises; agritourism

JEL codes: $\quad$ C33, F21

Received: 11 November $2014 \quad$ Revised: 17 February $2015 \quad$ Accepted: 2 March 2015

\section{Suggested citation:}

Dorocki, S., Szymańska, A.I., \& Zdon-Korzeniowska M. (2015). Family Agritourist Enterprises in Poland: Preliminary Survey Results. Entrepreneurial Business and Economics Review, 3(1): 151-163, DOI: http://dx.doi.org/10.15678/EBER.2015.030111. 


\section{INTRODUCTION}

The political and social-economic changes of 1990s in Poland contributed to a rapid growth of entrepreneurship, including family entrepreneurship. Piasecki referred to this period as to "an explosion of entrepreneurship" (Piasecki, 1998). The phenomenon a family business is a relatively new topic in scientific discussions. It was no sooner than in 1980 s that it emerged as the topic of serious scientific research in the United States of America and in the Western European countries (Jeżak, Popczyk \& Winnicka-Popczyk, 2004).

A family creates an environment supporting pro-entrepreneurial behaviour. Entrepreneurship is "the heart and soul" of most family-run enterprises. At the same time, family enterprises stimulate growth of entrepreneurship and may be the core and kernel of business at a large scale ${ }^{1}$. Family businesses guarantee economic stability. Because of their specificity, they play an important social and political role. According to Piasecki, this role consists in both creating the class of small proprietors and softening social tensions, as well and lowering the high social costs of the process of transformation. The propitious factors for those are the absorption of workforce surpluses and creating entrepreneurial attitudes, showing others the possibility of selfemployment, achieving success and changing the social status (Piasecki, 1998).

\section{LITERATURE REVIEW}

Family enterprises are the most important source of economic growth in the industrialised global economy, generating wealth and new jobs (Surdej \& Wach, 2012; Wach, 2014; Daszkiewicz \& Wach, 2014; Wojciechowski \& Wach, 2014). They represent a natural form of entrepreneurship which, given favourable conditions, may grow and run for many generations (Więcek-Janka, 2013). A growing interest in issues related to family businesses has been observed globally since 1970. Locally, in Poland, the research has spurred during the last decade. The key themes covered by the research are (WięcekJanka, 2013, p. 19):

- Managing family enterprises (e.g. Schulze, Lubatkin \& Dino, 2003; Anderson \& Reeb, 2004; Jeżak et al., 2004; Safin, 2007; Sułkowski \& Marjański, 2009; Miller, Le BretonMiller \& Lester, 2011; Lungeanu \& Ward, 2012; Więcek-Janka, 2013),

- Entrepreneurship (e.g. Sirmon \& Hitt, 2003; Villannueva \& Sapienza, 2009; Fan, Wenying, Xiaofei \& Bernat, 2012; Antoszkiewicz, 2012; Surdej \& Wach, 2010; Surdej \& Wach, 2011, Wach, 2014; Daszkiewicz \& Wach, 2014).

\footnotetext{
1 The complex research on the condition of family businesses conducted in 1990s (Shapero \& Sokol, 1982, pp. 72-90; Jeżak et al., 2004, pp. 16-17) confirms significant economic importance of family businesses for the economy. According to the report made by the Institute For Research on Entrepreneurship and the Economic Development (Instytut Badań nad Przedsiębiorczością i Rozwojem Ekonomicznym), family businesses represented between $50 \%$ to nearly $70-80 \%$ of all Polish businesses (Żurowski, 2008, p. 4; Surdej \& Wach, 2010, p. 7), whereas country-wide research conducted in Poland in 2009 by PENTOR Research International showed that the one-third of all Polish enterprises are family businesses. (The research on family businesses, the Final Report, 2009, p. 67; Surdej \& Wach, 2010, p. 7).
} 
- Finance in family enterprises (e.g. Anderson \& Reeb, 2003; Villalonga \& Amit, 2010),

- The economy (e.g. Bennedsen, Niel-sen, Pérez-González \& Wofenzon, 2006).

In spite of relatively rich literature on the topic, an unambiguous and generally accepted definition of the "family business" concept has not been formulated. This deficit is present when attempting to estimate the number of such enterprises as well as in other issues touched in research devoted to family entrepreneurship.

By analysing the methods used to define the concept of "family businesses" in the literature, there are several widely acknowledged criteria (Sten, 2006, Safin, 2007; Surdej \& Wach, 2010, 2011; Więcek-Janka, 2013):

- Ownership - the family is the sole or dominant owner,

- Management - the family is involved in managing the enterprise,

- Family succession - a transfer between generations (at least 2nd generation enterprises),

- Subjective criteria - an enterprise self-defined as a family enterprise.

With the criteria, the typology of family enterprises can be made. They represent one of more important research areas in the field of family businesses. Definitions of a family enterprise which are most often followed in the literature, combine two criteria: ownership and management. According to the above, a family enterprise is an enterprise with the family as the dominant or significant owner, involved in the process of managing the enterprise. However, the definition which is currently common in the literature, is a definition formulated by Sten (2006), which takes into account subjective criteria indicating that a family business is a business that believes to be a family business. There is little doubt that the dual nature of a family enterprise is its characteristic feature, which causes many practical and theoretical dilemma i.e. the entrepreneurial and family spheres overlap and merge, while these two spheres have different values and rights but, at the same time, both the objectives of the enterprise and of the family are equally important.

In the opinion of the authors of this paper, agritourist farms are a very special example of family entrepreneurship. They form a sector with nearly $100 \%$ of family business. Agritourist farms are an important branch of economic activity at the local, national and international level.

Research on agritourist enterprises or agritourism in general is mainly focused on the mechanisms creating conditions for their development. The research is carried out in different scientific disciplines e.g. farming, economics, social sciences and geography and has contributed to the emergence of such concepts and theoretical models as, e.g.:

- In economics - the rural tourism market operation model (Bott-Alama, 2004),

- In geography - agritourism development outcomes balance model (Wojciechowska, 2006),

- In agricultural sciences - the concepts of economics of agritourist farms and the dependence between the agricultural production and agritourism (Sznajder \& Przezbórska, 2006).

The term 'agritourism' is understood and interpreted in various ways both in professional literature and in the economic practice. It is common to identify agritourism directly with rural tourism or with tourism in the rural areas. Nevertheless, not going 
deeper into the systematics of the term, the concept of agritourism is based on the conviction that a farm is the tourist service supplier (Sznajder \& Przezbórska, 2006). Drzewiecki (2009, p. 9) gives a universal definition of contemporary agritourism pointing out that "it is a form of relaxation taking place in rural areas with the agricultural character, based on the accommodation and recreational activities connected with the farm or the equivalent one and its natural, production and service surrounding". However, as the authors point out, this definition, in particular its practical implications, do not reflect the full variety and dynamics of touristic service development in the rural areas and also the legal aspects connected with the Act on Freedom of Conducting Business Activity ${ }^{2}$ and the Act on Personal Income Tax ${ }^{3}$. According to the above mentioned acts, agricultural enterprises conducting agricultural business activity where the number of rooms offered for tourists is not higher than 5 are exempt both from the requirement to register their business and from taxation. In practice, though, it is area where farms stretch the limit of law to apply solutions exempting them from paying income tax. The status of a farmer is also often abused, often in consequence of property manipulation (Drzewiecki, 2009). Because of the above mentioned circumstances and ambiguities in terminology there are various types of buildings with touristic function.

Development of agritourism in Poland depends, first of all, on the attractiveness of rural areas for tourists, variety of landscape connected with the rural structure, traditional methods of agricultural production and rural cultural heritage resources.

Agritouristic family enterprises represent an important form of farm diversification (Kłodziński, 2001). They play an important role in activating areas, influence and stimulate local economic structures and, as a result, they create workplaces and generate new sources of income.

\section{MATERIAL AND METHODS}

The authors of the article, classifying agritourist farms to family enterprises, used the research questionnaire and the in-depth interview method in their research. The goal of the research, covering both the primary and the secondary data sources, was to analyse agritourist enterprises in Poland as an example of family enterprises, in terms of their market behaviour, entrepreneurial behaviour and behaviour related to generating innovation as well as identifying advantages and disadvantages of a family business according to agritourist enterprises (Dorocki, Rachwał, Szymańska \& Zdon-Korzeniowska, 2012, Dorocki, Szymańska \& Zdon-Korzeniowska, 2012, 2013a, 2013b).

The conducted desk research led to the formulation of the following research hypotheses: H1: Agritourist enterprises owners self-define themselves as owners of family
enterprises.

H2: Agritourist enterpr

\footnotetext{
${ }^{2}$ The Act of Freedom of Conducting Business Activity of 2nd July 2004, as amended.

${ }^{3}$ The Act of 26th July 1991 on Personal Income Tax, as amended.
} 
H3: Owners of family agritourist enterprises can see their advantage in being innovative and strive to introduce changes in their businesses.

Achievement of the above-mentioned goal was based on: (i) the analysis of professional literature, and empirical research conducted through; (ii) direct questionnaire surveys; (iii) individual in-depth interviews.

The empirical research was conducted in the period from January to March 2012. The process of data collecting included three phases. The first phase involved pilot studies (expert questions and questionnaire surveys with owners of 3 agritourist enterprises) to learn about the specifics of the agritourist business, verifying appropriateness of the surveying instrument (the questionnaire of the survey) and the degree of comprehension of the wording used in the questionnaire.

In the second phase of the research, a questionnaire survey followed with questionnaires sent out (via e-mail) to 1326 agricultural businesses all over Poland ${ }^{4}$. Finally, 46 agricultural enterprises took part in the questionnaire survey (the response rate of $0.034 \%)^{5}$.

In the third phase, a scenario of the in-depth interview (IDI) was developed on the basis of the research results. The scenario of the in-depth interview (IDI) was conducted with owners of 3 enterprises. Owners with many years' experience in the agritourism and differentiated offer were chosen: Na Zagrodzie run by Joanna and Dominik Wojtan (Lubien, the Małopolska Region) awarded in the 8th edition of Great Discovering of Malopolska in 2007 and ranking third in the Agritourism category; Ostoja owned by Jan and Ewa Szombara (Gietrzwałd, Warmia and Mazury Region), Willa Aba owned by Bernadeta Bukowiec (Tylicz, the Małopolskie Region). This interview was aimed at enhancing results of the survey.

The analysis involved descriptive statistics and was based on relative values illustrated by graphs.

\section{RESULTS AND DISCUSSION}

\section{Preliminary Survey Results}

All businesses offering agritouristic services (agritouristic farms) in Poland operate as farms or they self-proprietorship run in accordance with the rules of the Act on Freedom of Establishment and Personal Income Tax Act and in various organizational and legal forms. In the second case, the entity can be classified to enterprises. Agricultural activity of a farm, according to the authors, can also classify the farm as an enterprises. However, farmers in the touristic business are forced to look at their activities more through the needs of market. They have to take into account customers' needs, identify and monitor competitors' activities and, in this aspect, make an effort to prepare a suitable offer, with promotion, costing etc. Summarising, an agricultural enterprise

\footnotetext{
${ }^{4}$ The research for the paper in question covered agritouristic enterprises which are the members of agricultural associations under the umbrella of the Polish Association of Rural Tourism "Gospodarstwo Gościnne" (1 000 farms) and those shown in other associations and agritouristic portals (325).

${ }^{5}$ Authors assume that enterprises weren't interested in participating in the research and giving reliable answers.
} 
(either registered as business activity or operating as a farm) is a profit-oriented business (Sznajder \& Przezbórska, 2009).

The research for the paper in question covered agritouristic enterprises which are the members of agricultural associations under the umbrella of the Polish Association of Rural Tourism "Gospodarstwo Gościnne" (1 000 farms) and those shown in other associations and agritouristic portals (325). Among the enterprises analysed in the research, there were both those operating as farms and those which are registered as businesses. The research shows that $67 \%$ of the interviewed agritourist enterprises were rooted in the transformed farm and more than $17 \%$ came from businesses other than farming. However, approximately $15 \%$ of the interviewed enterprises operated as agricultural enterprises from the beginning (compare figure $1 \mathrm{~A}$ ). Nearly $72 \%$ of agricultural enterprises continue to operate as farms. About $43.5 \%$ of these farms do animal breeding, $39 \%$ grow crops, more than $17 \%$ orcharding, $13 \%$ operate in the fruit and vegetable processing industry, $6.5 \%$ in processing of animal products and approximately $4.3 \%$ are apiaries (Figure $1 \mathrm{~B}$ ).

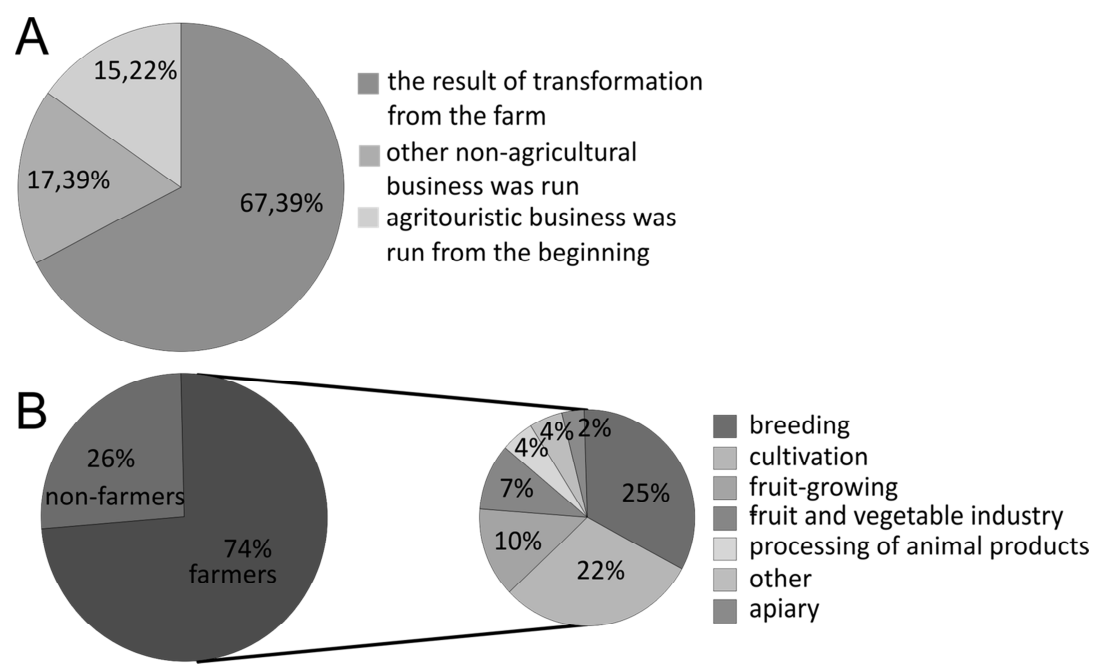

Figure 1. The origin of the interviewed agricultural enterprises $(A)$ and the structure of the continued agricultural activity (B)

Source: own elaboration based on the survey questionnaire $(n=46)$.

As mentioned above, agritourism, because of its specific character connected with delivering touristic services on the basis of assets of the farm or the equivalent one (frequently household) can be perceived a priori as family business. The agricultural enterprises taking part in the research were asked to indicate whether they would classify themselves in the family businesses or not. Nearly $89.1 \%$ of them consider themselves to be family businesses and merely $8.7 \%$ has a different opinion (Figure 2 ). 


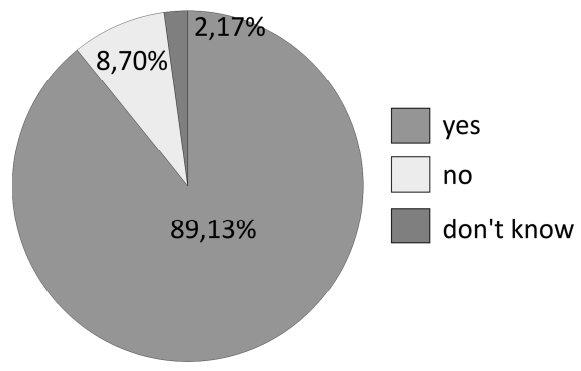

Figure 2. The share of family firms in agritourism among the investigated businesses according to the survey

Source: own elaboration based on the survey questionnaire $(n=46)$.

As far as the specific advantages and disadvantages, the majority of firms taking part in the research recognize numerous benefits in running a family business. According to the research results, they believe that:

- employees who are family members are more loyal (91.3\%);

- family members show more commitment (93.5\%);

- in crisis situations, one can rely more on support (also financial one) from family members rather than from persons from the outside of the family $(67.4 \%)$;

- family members take care more about assets of the business (91.3\%);

- family members are more engaged in the projects (82.6\%).

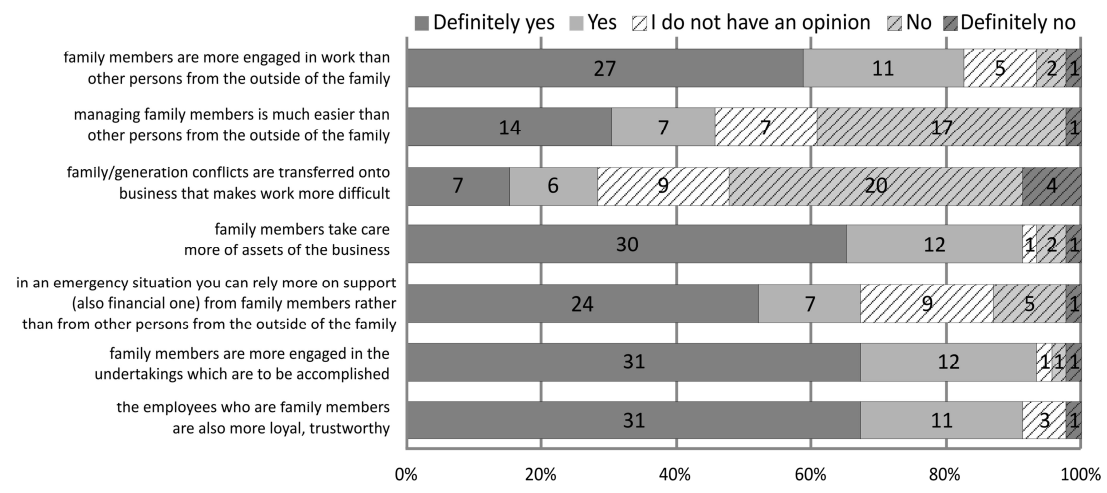

Figure 3. The opinions of the interviewed agricultural enterprises in the area of pros and cons resulting from running a family business Source: own elaboration based on the survey questionnaire $(n=46)$.

Nearly $52.2 \%$ of enterprises believe that family or generation conflicts are not transferred onto business and that they do not have influence on the functioning of the enterprise. The opinions on the degree of difficulty involved in managing family members are divided. Almost $46 \%$ of the respondents asses it as easier. However, $39 \%$ see certain difficulties in running a family business. Specific opinions of the interviewed agricultural enterprises in the area of benefits resulting from running a family business are presented in Figure 3. 
The farms taking part in the research claim that they strive for innovation. Product innovations are among manifestations this attitude. Up to $63 \%$ of the interviewed businesses declared that last year they introduced a new item in their offer. Unfortunately, no respondents specified the changes they made. The ideas in the introduced changes were the effect of customers' suggestions (36.4\%), observation of activity of other businesses $(24.2 \%)$ or own or family members' ideas (24.2\%). As little as $3.0 \%$ are the ideas drawn from training courses attended by employees of agricultural enterprises. The sources of product inspirations are depicted in Figure 4.

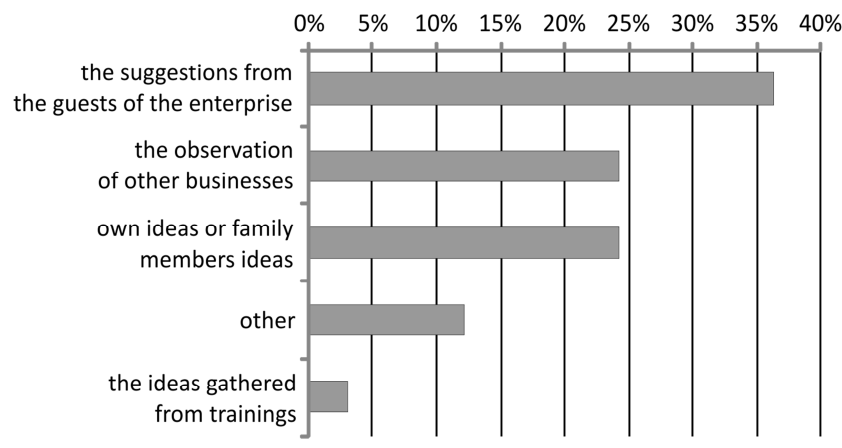

Figure 4. Sources of product innovation in agritourist enterprises

Source: own elaboration based on the survey questionnaire $(n=46)$.

To a large extent, survey respondents use information technologies such as the Internet, concerning the offer improvement and streamlining the service to customerstourists. Almost all agritourist enterprises participating in the survey had an Internet access (93.5\%) and nearly $83 \%$ had a wireless Internet access (WiFi). Most enterprises have their own website (93.5\%) updated when needed (54.5\%). In the case of almost $24 \%$ of the interviewed agritourist enterprises, the website is updated once a year or more often, while nearly $9 \%$ confirmed that they never update their website. Typically, an agricultural enterprise administers its own website $(56.5 \%)$ or uses the service at somebody's courtesy (19.6\%). Approximately $22 \%$ of agritouristic enterprises commissions this task to other firms.

Presence at social media (21.7\%), placing banners and advertisements in the local internet services $(15.2 \%)$ or mailing $(6.5 \%)$ are examples of innovative approach to also to the range of the tools used for promotion. Moreover, in the case of $63 \%$ agritourist enterprises, it is possible to book accommodation online.

As far as opening to new groups of customers is concerned (such as the disabled), unfortunately, the overwhelming majority of the surveyed infrastructure is not adapted to hosting the disabled people. This fact was confirmed by $83 \%$ of the agritourist enterprises which participated in the survey. More than $54 \%$ declared that they check the degree of customers' satisfaction and $37 \%$ does that only occasionally and only slightly above $17 \%$ of the respondents do it on regular basis. Conversation about that topic is the most common form of checking that. Almost $70 \%$ of the customers use this 
method of customer satisfaction control whereas only $13 \%$ of agritourist enterprises organise a survey among their customers.

On the other hand, it seems that agritourism enterprises do not show entrepreneurial spirit when it comes to the opportunities of receiving financing from the EU funds. Only $28 \%{ }^{6}$ of agritourist enterprises applied for financing their activity from the EU funds and as much as $71.7 \%$ have not taken such actions. It is interesting that the surveyed agritouristic enterprises, in their overwhelming majority, show a highly active attitude when it comes to broadening their knowledge of tourism and agritourism. Such declaration was made by nearly $91 \%$ of agritourist enterprises. Also $91 \%$ of the surveyed confirmed that they regularly take training courses. $39 \%$ of the agritouristic enterprises go on a training course at one's own expense and out of their own initiative. Nearly $24 \%$ participate in trainings organized by the local government.

\section{Preliminary Interview Results "Na Zagrodzie" ("On the Farm") Family Agritourist Enterprise}

The last stage of the research involved a direct, in-depth interview with Mr Dominik Wojtan, the owner of "Na Zagrodzie" ("On the Farm") agritourist enterprise. Conducting an interview with an expert in the research subject resulted in adding more details to the data collected in a standard questionnaire survey. The scenario of the survey consisted of three groups of questions asking the respondent's opinion on the enterprise being a family business, the area of innovation and on entrepreneurship in the enterprise.

As it was mentioned earlier, agritourist enterprises are family centred businesses. This was confirmed during the in-depth interview. According to the respondent's declaration, all family members participate both in work on the farm and in taking important decisions connected with its functioning. Moreover, "Na Zagrodzie" farm, operating as such since 2003, has continued family traditions of providing service for tourists since 1970 s and this activity is passed from one generation to another.

The owner sees many advantages of a family business, not only for the business but also for family, including:

- self-sufficiency

- shared work such as managing an enterprise unites the family, which in turn is helpful in building mutual trust, sense of security and responsibility not only for oneself, but also for the property and assets;

- possible conflict- solving teaches compromise and dialogue across generations.

In the case of family businesses their owners look into the future more often than in the case of other businesses and they think of succession in the enterprise. Working together on the farm, taking the important decisions for the enterprise together with younger generations help comprehend the specific character of the branch and business which the succession by the next generation. According to "Na Zagrodzie" agritouristic enterprise owners, the perspective of succession of the business is a motivating factor in

\footnotetext{
${ }^{6}$ The real number of application forms submitted for aid from EU funds for the sake of financing the activities concerning agritourism can be even lower because of the fact that the number of agricultural enterprises functioning within the frames of farms interprets EU subsidies as direct payment to agriculture and this matter has not been clearly separated by the Authors in the research.
} 
relation to which they take action concerning education and developing certain competences of their successors (their children). The owners point that their children learn openness to others, communication skills. Parents send them to language courses to shape features and competences essential for delivering high quality touristic and customer service.

The analysis of the enterprises (including their offer) and the information gained by means of in-depth interviews helps to classify the farm in question, an innovative one. Ostrich breeding, continuous effort towards broadening the business offer and its increasing its attractiveness to bring more buyers of the new animals (a cow, sheep, pigs, hens, ducks, turkeys), organizing open-air and integration meetings and also the plans to introduce the next attractions (creating a playground for children, a football pitch, a rope park) prove the innovative nature of this agritourist enterprise. The owner sees innovation as the immanent feature of the entrepreneurship. He defines as: "the ability to run a business (an enterprise), creating new technologies, products, possibilities so as to achieve the effect in the shape of revenue from that enterprise" ${ }^{7}$ He perceives himself as an innovative person mostly due to the fact that he introduces innovations ${ }^{8}$, which he understands as "creating something better, improving something existing" ${ }^{\text {. As the }}$ owner points out primarily the source of these innovations are as follows:

- customers - "the conversations with guests who give suggestions concerning their expectations"

- competitors - "watching other agritouristic enterprises by websites, agritouristic fairs" ${ }^{\prime 1}$;

- owners - "own ideas"12.

\section{CONCLUSIONS}

Agritourism, as a branch of tourism and economy, is the area particularly fit for the development of family businesses. The family history is, among others, a factor which influences the creation and development of the entrepreneurial spirit (understood both as features, skills and activities involved in running the business). Entrepreneurs are often recruited from the families that have a history of small businesses, freelancers or farm owners. Farms are therefore a potential area for development of family entrepreneurship. Agritourism is an opportunity and an attractive alternative for unprofitable farming (in particular, on a small scale). On the one hand, the combination of a tourist offer and farming contributes to increasing profitability of farms and, on the other hand, enhances the attractiveness of the tourist offer. Moreover, such a mix

\footnotetext{
${ }^{7} \mathrm{~A}$ statement made by the owner in an interview for the research in question.

8 "I constantly introduce something new in my enterprises to attract customers, I keep on improving things, changing, creating new offers so yes, I am entrepreneurial". A statement made by the owner during an interview conducted for the research.

${ }^{9}$ A statement made by the owner in an interview for the research in question.

${ }^{10}$ A statement made by the owner in an interview for the research in question.

${ }^{11}$ A statement made by the owner in an interview for the research in question.

${ }^{12}$ A statement made by the owner in an interview for the research in question.
} 
contributes to preserving traditional activities, agriculture, Polish country heritage and identity.

Issues analysed in this study are relatively new and poorly covered by the literature in the field. The research problems in agritourism focus largely on its development conditions as a social and economic phenomenon i.e. a more to be considered at the mezzo and macro scale and a micro scale. The agritourist enterprise operation and management sphere has not been analysed in deep. A certain difficulty in analysing this group of entities comes from the inability to determine the exact number of agritourist enterprises. As it is, not all farmers reported room rental to the accommodation register kept by the competent municipal authority (head of village, mayor). Nevertheless, the topic of family entrepreneurship in agritourism appears as a rich and interesting research area, in particular when referred to:

- the issue of succession;

- management of the enterprises;

- market behaviours of the type of enterprises;

- specifics of family entrepreneurship in the field of agritourism in its comparison to other sectors.

\section{REFERENCES}

Anderson, R.C, \& Reeb, D. (2003). Family ownership, corporate diversification, and firm leverage. Journal of Law and Economics, 46, 653-684.

Anderson, R.C, \& Reeb, D. (2004). Board Composition: Balancing Family Influence in S\&P 500 Firms. Administrative Science Quarterly, 49, 209-237.

Antoszkiewicz, J.D. (2012). Funkcjonowanie firmy rodzinnej w świetle zasady Pareto - 20/80. Przedsiębiorczość i Zarzqdzanie, 13(8), 219-251.

Bennedsen, M., Nielsen, K.M., Perez-Gonzales, F., \& Wolfenzon, D. (2006). [online] Inside the family firm: the role of families in succession decisions and performance. Retrieved online on November 18, 2014 from: <http://www.nber.org/ papers/w12356>.

Bott-Alama, A. (2004). Uwarunkowania rozwoju turystyki wiejskiej w województwie zachodniopomorskim. Szczecin: Wydawnictwo Naukowe Uniwersytetu Szczecińskiego.

Daszkiewicz, N., \& Wach, K. (2014). motives for going international and entry modes of family firms in Poland. Journal of Intercultural Management, 6(2), 5-18.

Dorocki, S., Rachwał, T., Szymańska, A.I., \& Zdon-Korzeniowska, M. (2012). Spatial conditions for agritourism development on the example of Poland and France. Current Issues of Tourism Research, 2(2), 20-29.

Dorocki, S., Szymańska, A.l., \& Zdon-Korzeniowska, M. (2012). Polskie gospodarstwa agroturystyczne jako przedsiębiorstwa rodzinne. Przedsiębiorczość i Zarzq̨dzanie, 8(8), 45-60.

Dorocki, S., Szymańska, A.I., \& Zdon-Korzeniowska, M. (2013a). Przedsiębiorstwa agroturystyczne w gospodarce opartej na wiedzy. Prace Komisji Geografii Przemysłu Polskiego Towarzystwa Geograficznego, 24, 38-58.

Dorocki, S., Szymańska, A.I., \& Zdon-Korzeniowska, M. (2013b). Polskie gospodarstwa agroturystyczne w dobie kryzysu gospodarczego. Przedsiębiorczość - Edukacja, 9, 175- 184.

Drzewiecki, M. (2009). Agroturystyka współczesna w Polsce. Gdańsk: Wyższa Szkoła Turystyki i Hotelarstwa w Gdańsku. 
Fan, Z., Wenying, W.U., Xiaofei, Q., \& Bernat, M. (2012). A microcosm of the conterprorary Chinese family business - the ebb and flow of Wenzhou model. Przedsiębiorczość i Zarzqdzanie, 13(8), 359-375.

Jeżak, J., Popczyk, W., \& Winnicka-Popczyk, A. (2004). Przedsiębiorstwo rodzinne. Funkcjonowanie i rozwój. Warszawa: Difin.

Kłodziński, M. (Ed.) (2001). Gospodarka, człowiek, środowisko na obszarach wiejskich. Warszawa: IRWiR PAN.

Lungeanu, R. \& Ward, J.L. (2012). A governance-based typology of family foundations: the effect of generation stage and governance structure on family philanthropic activities. Family Business Review, 25(4), 409-424.

Miller, D., Le Breton-Miller, I., \& Lester, R.H. (2011). Family and lone-founder ownership and strategic behavior: social context, identity and institutional logics. Journal of Management Studies, 48(1), 1-25.

Safin, K. (2007). Przedsiębiorstwa Rodzinne - Istota i Zachowania Strategiczne. Wrocław: Wydawnictwo Akademii Ekonomicznej im. Oskara Langego we Wrocławiu.

Schulze, W., Lubatkin, M.H., \& Dino, R.N. (2003). Toward a theory of agency and altruism in family firms. The Journal of Business Venturing, 18(4), 473-490.

Shapero, A., \& Sokol, L. (1982). The social dimensions of entrepreneurship. In C. Kent, D. Sexton, \& K. Vesper (Eds.), Encyclopaedia of Entrepreneurship (pp. 72-90). Engelwood Cliffs, NJ: PrenticeHall.

Sirmon, D.G., \& Hitt, M.A. (2003). A model of strategic entrepreneurship: the construct and its dimensions. Journal of Management 29, 963-989.

Sten, J. (2006). Transfer of family business to non-family buyers. The selling business family perspective. Helsinki: Helsingfors.

Sułkowski, Ł., Mariański, A. (2009). Jak Osiqgnąć Sukces w Sztafecie Pokoleń? Warsztaty Menadżerskie. Warszawa: Poltext.

Surdej, A., \& Wach, K., (2010). Przedsiębiorstwa rodzinne wobec wyzwań sukcesji. Warszawa: Difin.

Surdej, A., \& Wach, K. (2011). Sucession Choice in Family Businesses. The Case of Poland. Torun: Wydawnictwo Adam Marszałek.

Surdej, A., \& Wach, K. (2012). The dynamics of succession in family businesses in Poland - Empirical results. Economia Marche. Journal of Applied Economics, 31(2), 109-128.

Sznajder M., \& Przezbórska L. (2006). Agroturystyka. Warszawa PWE.

Villalonga, B., \& Amit, R. (2010). Family control of firms and industries. Financial Management, 39, 863-904.

Villanueva, J., \& Sapienza, H. (2009). Goal tolerance, outside investors, and family firm governance. Entrepreneurship: Theory and Practice, 33(6), 1193-1199.

Wach, K. (2014). Familiness and Born Globals: Rapid Internationalisation among Polish Family Firms. Journal of Intercultural Management, 6(3), 177-186.

Wojciechowski, L., \& Wach, K. (2014). The size and the strategic international orientation: the use of eprg model among Polish family and non-family firms. Przedsiębiorczość i Zarzq̨dzanie, $X V(7[1]), 143-156$.

Więcek-Janka, E. (2013). Wiodqce wartości w zarzqdzaniu przedsiębiorstwami rodzinnymi. Poznań: Wydawnictwo Politechniki Poznańskiej.

Wojciechowska, J. (2006). Bilans efektów rozwoju agroturystyki. Turyzm, 16(2), 65-74. 
Żurowski, R. (2008). Overview of Family Business Relevant Issues. Country Fiche Poland, ŁódźVienna: Instytut Badań nad Przedsiębiorczością i Rozwojem Ekonomicznym, Austrian Institute for SME Research, European Commission.

\title{
Authors
}

The contribution of co-authors is equal and can be expressed as 33\% each of the authors: S. Dorocki prepared statistical analysis and calculations while A.I Szymańska and M. ZdonKorzeniowska prepared the literature review, research tools, research methodology and final conclusions.

\section{Sławomir Dorocki}

Assistant Professor of the Pedagogical University of Cracow (Poland), at the Faculty of Biology and Geography, Institute of Geography, Department of Entrepreneurship and Spatial Management. PhD in History.

\section{Anna Irena Szymańska}

Assistant Professor of the Pedagogical University of Cracow (Poland), at the Faculty of Biology and Geography, Institute of Geography, Department of Entrepreneurship and Spatial Management. PhD in Economy.

\section{Małgorzata Zdon-Korzeniowska}

Assistant Professor of the Pedagogical University of Cracow (Poland), at the Faculty of Biology and Geography, Institute of Geography, Department of Entrepreneurship and Spatial Management. PhD in Economy.

\author{
Correspondence to: \\ Małgorzata Zdon-Korzeniowska, PhD \\ Pedagogical University of Cracow \\ Institute of Geography \\ Department of Entrepreneurship and Spatial Management \\ ul. Podchorążych 2, 30-084 Kraków, Poland \\ mkorzen@up.krakow.pl
}

\section{Acknowledgement and Financial Disclosure}

The authors would like to thank the anonymous referees for their useful comments, which allowed to increase the value of this article. The authors would like to express their gratitude to Joanna and Dominik Wojtan for their help.

\section{Copyright and License}

This article is published under the terms of the Creative Commons Attribution - NonCommercial - NoDerivs (CC BY-NC-ND 3.0) License http://creativecommons.org/licenses/by-nc-nd/3.0/ 
